\title{
Philosophical and Therapeutic Aspects of the Platonic "Drama": Andrew Irvine's Socrates on Trial
}

\author{
Anna Lazou \& Giannis Spyridis ${ }^{1}$ \\ University of Athens - UOA, Philosophical School, GREECE
}

Received 24 June 2019 • Revised 28 September 2019 • Accepted 1 October 2019

\begin{abstract}
The present article is written on the occasion of staging Socrates on Trial in Athens. The authors want to reveal unexplored psychological (such as the problem of personal identity, human relations, therapeutic needs of modern man etc.) and social aspects and situations (e.g. problem of justice, social role of the wise man, philosophy in education etc.) that those involved in the specific dramatization have faced with. The application of the Socratic dialectic in the theatrical presentation of philosophical ideas is discussed within the contemporary context of philosophical counseling and various therapeutic activities - such as the so-called philosophical "Praxis" since the 1970's. We argue in favor of a validly applied interrelation between philosophy and theatre today in which the platonic drama proves to be of great value as a literature genre that stands among them. Therefore we support that in Andrew Irvine's play and the experience of staging Socrates on Trial in its Greek version, we have a genuine example of an educational and therapeutic application of philosophy through art.
\end{abstract}

Keywords: Socrates, Platonic drama, philosophical counseling, art and philosophy, Socratic dialectic.

\section{Introduction}

A crucial for our times question that Andrew Irvine's play (Irvine 2008, Lazou \& Patios, 2017, v. B ')2 raised to its reader and spectator is:

"Can philosophy face barbarism effectively? With the intention of rethinking together - actors on stage and spectators - this old and always timely question, the many characters of the play, integrated into an interactive frame, we support the contemporary reconstruction of Heliaia's court with the collective effort of amateurs and the creative collaboration of young artists and professionals - on a voluntary

${ }^{1} \mathrm{PhD}$ candidate of philosophy.

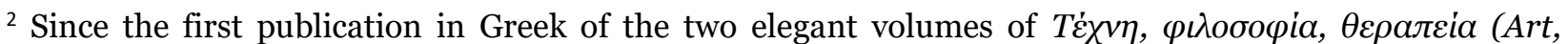
Philosophy, Therapy 2016 - 2017) by Arnaoutis Books [with covers and backs adorned with the paintings of the great Nikos Engonopoulos], with the second volume dedicated to Andrew Irvine's Socrates on Trial including an introduction and prefatory notes by annotated Professors of Philosophy and also photographs of the Greek and international presentations of the play. Recent book review: http://approaches.gr/psaltopoulou-br20190725 and https://www.facebook.com/approaches.journal/.

(C) Authors. Terms and conditions of Creative Commons Attribution 4.0 International (CC BY 4.0) apply. Correspondence: Anna Lazou, University of Athens - UOA, Philosophical School, GREECE. E-mail: lazou2011.ancientorchesis@gmail.com. 
and non-profiting basis. Spectators are invited during the performance to vote for or against Socrates, thus submitting philosophy - which is represented by the famous figure of the ancient wise man - to the test of contemporary criticism." (Lazou \& Patios, 2017, 23)3

What is one of the most controversial matters for actors and directors though, is the application through theatrical art of an alternative therapeutic practice that teaches and promotes at the same time such important values as democracy, justice and collectivity; at first hand, we support that this goal of a theatrical project like the one we experienced with Andrew Irvine's Socrates on Trial, could enrich philosophical didactics within the University by adding an innovative and wider, as well as socio-political perspective, outside the typical classroom and different than the established academic learning processes (Lazou \& Patios, 2017: 24). So, the present article written in common by the director (Anna Lazou) and the translator (Giannis Spyridis) of the Greek version of Socrates on Trial will argue for such an interpretation and relevant proposal for the practices of theatre and philosophy in a therapeutic context.

While, by translating Professor Irvine's play, it is possible to understand the philosophical implications arising, because the present text is an array of ideas and philosophical positions that were the very essence of teaching in the ancient world, perhaps the most outstanding part in the experience of reviving Socrates' story is its diachronic influence: the fact that we all share the same familiarity with the events which took place 2500 years ago. In literature, similar paradigmatic examples provide the reader with alternative opportunities for reflection: major authors and play rights, such as William Shakespeare, Manuel De Cervantes, Leon Tolstoy, Victor Hugo, etc., have and keep on broadening our spiritual horizons by placing high standards to our cognitive and critical ability. With such equipment provided by historical literature and playwriting, we may become capable of compensation "in front of the eyes" of the then condemned to death Athenian philosopher, revived on stage and perhaps, finally, be liberated from the moral bondage of our consciousness by exclaiming "innocent" (Lazou \& Patios, 2017: 2930). Theatrical stage, anyway, is an integral part of the human world and therefore the art of theatre may be transformed into an art of living.

\section{Theatre and/as philosophy}

The point about the distinction and at the same time concurrency of theatre and philosophy, both in history and from an analytic point of view, has been commented to the point by Byron Kaldis in his prefatory note (Lazou \& Patios, 2017: 7) to the Greek edition of Socrates on Trial:

\footnotetext{
"Theatre and Philosophy are venerable human intellectual activities, each as old as the other, both of them emerging simultaneously as ingredients of the origins of European civilization. Yet despite going back in time more or less in tandem, and despite having been subjects of critical thought right from the start, linking them or studying their relationship or their common elements as well as their differences, it is only fairly recently that philosophy, as an established academic discipline and professional specialization, has officially inaugurated a specific branch studying theatre-in-action as an explicitly distinct field of its own. What is more, this has happened both outside traditionally understood aesthetics, though to a certain extent this new specialization overlaps with aesthetics or the philosophy of art, but moreover it has also happened from a novel standpoint: a central branch of the new field is officially named "performance philosophy" (and "performance studies")
}

\footnotetext{
${ }^{3}$ According to the director's note.
} 
indicating the new origins and novel aim. ${ }^{4}$ The name is coined to capture best the moving away from theatre understood foundationally or principally as a silent text waiting to be read and consequently a moving away from philosophical criticism and philosophical investigation as simply textual or poetic aesthetics or a kind of semantic analysis."

Besides these important issues considering the historico-analytical relationship of theatre and philosophy, as pointed out emphatically by Professor Kaldis, our effort in staging Socrates on Trial is confronted with a series of potentialities and their relevant problems raised by the practical applications of philosophy proposed by the so called philosophical counseling $(P h C)$; people like Lou Marinoff so warmly have recently supported practical philosophy outside the academic environment. Before proposing in more detail our approach concerning a contemporary therapeutic, as well as educational, application of philosophy in theatre by reference to the exemplary Socratic figure, let us attempt certain preliminary clarifications about such controversial notions and questions - and of great impact in our world - like the ones concerning the moral status of art, therapy or dialectics, which are bound to the $P h C$ trend or practical philosophy. Since we invite our audience today to be part of an experiential representation of Socrates' world and even undertake an active role as members of a metaphoric Heliaia Court, we should examine whether by doing so, we at the same time produce a therapeutic environment for modern man, in what sense and to what extent.

\section{The figure of Socrates in philosophical counseling and practical philosophy}

Lou Marinoff, as one of the initiators of PhC practices through his best seller Plato not Prozac, and continuing as the founding president of the American Philosophical Practitioners Association and editor-in-chief of its journal Philosophical Practice, thinks that philosophy may be a promising new form of a popular and alternative to religions or failed psychology/psychiatry methods, art of life (Brenifier 2017, Foucault 2005), 5 basing his approach on the analytic trend of philosophy that goes further than traditional rationalistic theory - practice philosophies. ${ }^{6}$ Similarly, Ran Lahav, defines the role of $P h C$ as a dialogic investigation between the individual/client and the advisor, where self - examination is being followed in philosophical terms, even if the addressed question or dilemma and life - issue are not of philosophical nature, but can be anything that bothers the man in the street (Lahav, 1996, 259). The aim of PhC has been stated as helping the individual understand one's problems and, through dialogue, exchange views and ideas with trained counselors, in order to find solutions grounded on the individual's personal way of thinking. It is up to the counselor to point out the many different perspectives, and potential approaches (Raabe, 2001).7 According to Zoran Kojčić, an author with major recent

\footnotetext{
4 Interest in performance has surged forward so much so that it is now being seen as an important but neglected aspect even of the most "silent" of aesthetic experiences, reading literature: cf. Kivy P., The Performance of Reading: An Essay in the Philosophy of Literature, Blackwell, Oxford, 2006 (Prof. Kaldis' reference, ibid.).

5 Lou Marinoff, Professor of Philosophy (theory, ethics, Buddhism, Chinese Philosophy, philosophical practice) at the City College of New York, and well known for his many books and publications (The Middle Way: Finding Happiness in a World of Extremes; Therapy for the Sane: How Philosophy Can Change Your Life; Fair New World, a novel etc.), he is also a classical guitarist, nature photographer, film director, and three-time Canadian Open Table Hockey champion.

6 Metaphilosophy, critical philosophy, bioethics and medical or even environmental ethics provide analogous patterns.

7 Peter B. Raabe characterizes $P h C$ as a procedure of the teacher providing the advised with "tools" for improving one's personal thinking.
} 
research on this topic with a completed PhD thesis at Sofia University, titled Performance Oriented Method in Philosophical Counseling:

"This new method aims to promote philosophizing as a practice which has an important role in self-development and builds on the notion of taking care of the self through investigation and concrete actions." (Kojčić, 2019: 93)

Since its emergence in 1980, several different notions, following different influences developed in the field of $P h C$, remaining even today without much recognition among the academic philosophers, but deeply in its core stands philosophical dialogue and its impact on everyday life of the contemporary man. PhC approach to applied or practical philosophy even before Lou Marinoff's or others' publications in the 1990's, had been tested in the Philosophical Praxis offices of Germany and Holland that offered miscellaneous therapeutic services to the general public and the interested in philosophy and philosophizing citizens. So, the trend of $P h C$ keeps growing rapidly around the world, "in Central and Western Europe, Scandinavia, US, Canada, South Africa, Russia, and lately also in the Balkans region” (Kojčić, 2019, 95), with such different practices "as public talks or interviews in England, philosophy in prison in US or Norway, Philosophy for Children, Philosophical Cafés, etc.” (Kojčić, 2019, 118), sometimes with a lack of a method either misusing the old methods or with philosophical mistakes and misunderstandings (Lou Marinoff, 1999). In a Socratic perspective, as Robert Walsh says, there is "a conversational process guided by dialectical reasoning" (Walsh, 2005: 501), theory and practice are vastly used by philosophical practitioners and this makes them quite different than academic researchers and professors. Through Philosophical Praxis and Counseling we share an already established application of philosophical dialogue, and the Socratic dialogue more specifically, in everyman's life, for purposes touching human reality apart from the usual academic structures; it is here that we may find our own point of crossing with an artistic proposal like ours.

One step further to our argumentation for a therapeutic application of Socrates' figure today is the already stressed affinities of the Socratic Method with Cognitive Psychotherapy, especially in cognitive therapy $(C T)$ models like those applied by Aaron Beck or educational counseling methods by Leonard Nelson, Gustav Heckmann and Pierre Grimes. Tracing the modern therapeutic background of philosophy it is advisable to come to contact with the Jungian Transcendent Function and the Foucaultian care of the Self - having in mind, still, that our perspective is different. Inspiring educators, counselors, psychotherapists and family therapists apart from philosophers, appeal to the Socratic ideas, which prove to be even in the $21^{\text {st }}$ century a perennial legacy of life techniques that influence modern man of all social levels or cultures and ages (Broad 2006).

The Socratic Method of teaching and philosophical inquiry where Socrates valued and examined carefully any question coming from his students with humor, care and patience, which shows his appreciation for the significance of personal bond and teacher - disciples emotional relationship that has been seen as a tool of self-discovery and healing. Moreover, Socrates' stance as described in the platonic dialogues presents a pattern of philosophical cure of the erroneous or "diseased" thinking, which may be thought as deprived of self-awareness; this is why the ways of thinking may be connected with certain forms of emotional pathology or excesses, anger or violence (Grimes \& Uliana, 1998; Corey, 2001; Cornford, 1996). Discussion described in the Platonic dialogues has been compared with the supposedly therapeutic dialogue taking place during the counseling session in a confidential atmosphere, with the use of a series of open questions on the part of the counselor and their anticipated answers by the client (Overholser, 2010, 2; Corey, 2001; Brickhouse \& Smith, 1994/2004).

There is a substantial difference between the Platonic "drama" and the actual discussions in the counselor's office, a difference beyond the directness, sincere and active character of both. Of course, the contemporary therapist as another Socrates, might claim 
ignorance ( $\dot{\alpha} \pi$ ло $\dot{\alpha} \alpha)$ of the ultimate truth or lack of possession of an academic recipe for acquiring it. Through questions and by brainstorming syllogisms the discussers reach truth in a constructive process while they both confess trust to logic and inductive reasoning. The Socratic sortlike examination of the contradictions or emotional excesses of the interlocutors (as well as his own), as a process, is a challenging play of words and free thinking which aim at provoking man's established beliefs about oneself:

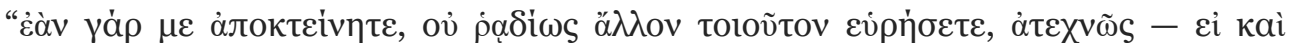

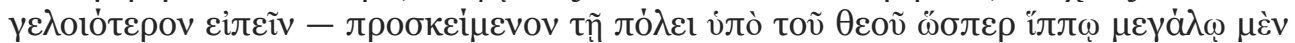

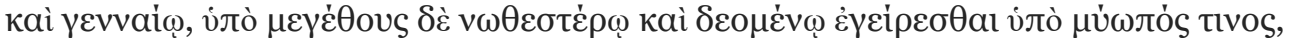

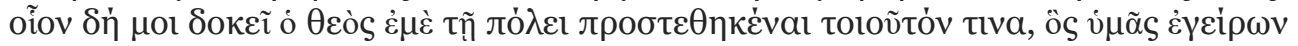

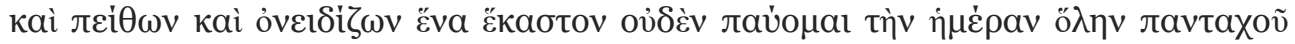

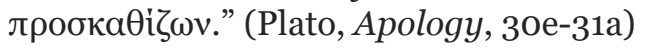

Like a bothering horsefly Socrates tries to stimulate with the dialogue man's reason and emotions in a quest for common-sense or universal truths - i.e., definitions or concepts that hold the same value and meaning for everyone, reminding us of terms and processes used in

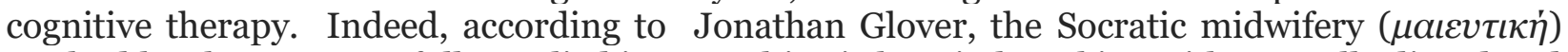
method has been successfully applied in a psychiatric hospital working with mentally disordered criminals, ${ }^{8}$ which became the proof of existence of moral consciousness - of a certain kind - in the allegedly "immoral" individuals: Professor Glover was asking these men seemingly simple questions, such as what they would teach a child to learn in order to be able to separate what is right from the wrong and was getting more or less predictably shallow answers; or answers with an explicit self-interest. The scientist, however, tried to go deeper into the minds of the patients using the well-known legend of Plato about Gyges' (a shepherd of the King of Lydia) ring, ${ }^{9}$ who finds a magic ring that allows his owner to become invisible at will and asking them whether they would commit a crime without being perceived. So, he discovered that many of the men had a vocabulary of moral concepts such as justice and respect, which throws a bridge linking people with illness or in conditions of social exclusion to others and so applying in an innovative way the Socratic explication of truth and moral consciousness. The consultant in the Philosophical Counseling $(P h C)$ procedures is thought to have a lot in common with the Socratic approach of the philosopher as the "midwife" of the client's ideas with the goal, as we already have said above, that with a critical analysis of his/her concepts he/she would apply the acquired knowledge to various instances of life.

Socratic dialogue, still, is to be discriminated from the psychoanalytic or cognitive psychotherapies that follow a practical "behaviorism" and introduce the person to specific cognitive frameworks where the subjective standpoint is secured and somehow approved without putting forward philosophical autonomy of both thought and act. ${ }^{10}$ One has to reconsider the

8 This experiment has taken place at Broadmoor Hospital in South England since the 1990s. Professor Glover began discussing moral issues with patients trying to explore a stereotype that followed them and they were not conscious of. These dialogues were the starting point for the writing of his book Alien Landscapes? Interpreting Disordered Minds (Glover, 2014), a book that is a philosophical study of Psychology but at the same time a psychological study of Philosophy. Dr. Glover, as an ethics professor at King's College, is accustomed to using the Socratic method to help his students "exalt" their ethics by answering difficult philosophical questions.

9 Plato, Rep., 2.359d-2.36od.

10 Dialogue as the quadratic root of the act that concentrates on "doing it on its own" in Plato: "[161 $\beta]$

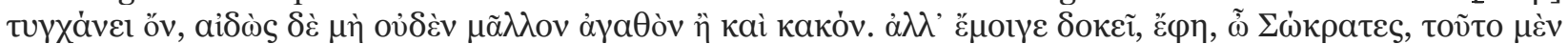

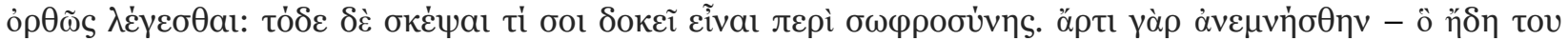

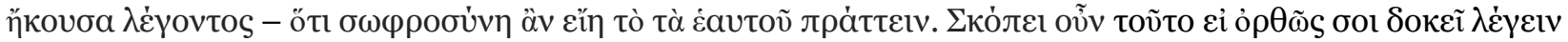

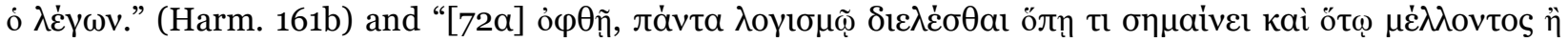

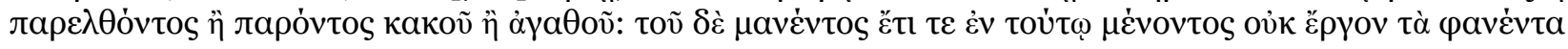


nature of dialectic as the rule-based discussion between individuals who have previously agreed to engage in the examination of moral, logical and ontological concepts searching for truth unconditionally. Truth is revealed to the individual through the next stage of the exercise of $\mu \alpha \iota \varepsilon v \tau \iota \kappa \dot{\eta}$, in the exercise of $\delta \iota \alpha \lambda \varepsilon \kappa \tau \iota \kappa \dot{\eta}$, the dialectic, actually by the individual's introduction to a particular sort of inferential logic and the recognition and acceptance of one's ignorance

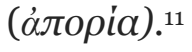

Another interesting conclusion may be derived by comparing Carl G. Jung's method of transcendent function - which is working with symbols, archetypes and images - with the Socratic questioning of rather cognitive character - working with believes, schemata and thoughts (Miller, 2004). The Jungian analyst in particular focuses on emotional traumas and their origin, which is to be found in conflicts between unconscious and conscious experiences and images and follows usually an elaborate slow-pacing approach of psychic blocks and behavioral problems.

Comparing the various therapeutic techniques employed by modern psychotherapy (cognitive or Jungian) and inspired by the Socratic practical philosophy, we may realize that the Socratic Method constitutes a perennial practical model of the art of life and self-improvement far beyond a mere technique of reasoning and mediation of passions or even further than a special kind of treating abnormal or "diseased" thinking; it is about a complete worldview according to which the ancient wisdom meets the needs of modern man (Padesky, 1993). In this context, education, politics and even history are important dimensions of a modern application of the Socratic method.

On the grounds of such Platonic dialogues like Protagoras, the Republic, Phaedo, Phaedrus or the Laws, a tradition of the Socratic influence on education, politics and philosophy of law originates, with the application of dialogue, as main method in these three cultural areas. ${ }^{12}$ Laura Candiotto in a thorough recent article of hers attempts:

\begin{abstract}
"to demonstrate how the fulcrum of the relation between the Socratic dialogue and politics can be individuated in every day philosophical practice, pursued in the social dimension of relationships, and intended as an educational device that aspires for the transformation of the epistemic agent and of her/his environment." (Candiotto, 2017a)
\end{abstract}

This author argues in favour of a line of $20^{\text {th }}$ century thinkers conforming what she calls to be the German tradition of applying the Socratic dialogue in the above context: she refers to Leonard Nelson, Gustav Heckmann and Minna Specht and to the well-known Friesian School of Education (Heckmann, 1981; Nelson, 1970; Nelson, 1929; Specht, 1944). Candiotto maintains that these German interpreters of the Socratic dialogue in the historical context of the $2^{\text {nd }}$ World War and the rise of Nazism in Europe provide us today with a significant version of Socrates' influence that reunites the ancient with the contemporary world since its main parameter is

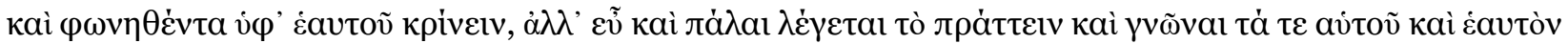

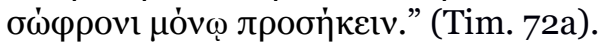

${ }^{11}$ These relationships between $P h C$ and the Socratic method have been repeatedly stressed by authors in the field like Tim LeBon (LeBon, 2001) or the practitioner of $P h C$ in New York Ronald Gross (Gross, 2002). Meanwhile, the application of Socratic questioning in various forms and levels of cognitive therapy is recognized and explicated by major cognitive therapists like Aaron and Judith Beck (Beck et al., 2011). See Lageman, 1989 and American Society for Philosophy, Counseling \& Psychotherapy, 2007: www.aspcp.org; American Philosophical Practitioners Association, 1999-2011: http://www.appa.edu/.

${ }^{12}$ According to Plato, the task of education is mainly to form worthy human beings and right laws. Paideia was in fact a stable initiative in Plato's life and quest - to be definitely connected with Socrates as a teaching personality and with the very essence of the practice of philosophy, also connected critically with political life and the claim for social improvement and change.
} 
"evaluation the existential nexus connecting philosophical dialogue, education and politics" (Candiotto, 2017a).13 What is interesting about Candiotto's work and her revival of the German version in the political application of the Socratic dialogue, is her conjecture about the relatedness of Jan Slaby's account on affective intentionality with its emphasis on the bodily existence of the interlocutors, as an existential priority in every dialogue (Slaby, 2008);14 on Nelson's and Fries' terms, it is noted that at the ground of every philosophical analysis lies "the embodied, embedded, enactive and affective experience of the student” (Candiotto, 2017a; cf. Brown, 1965).15

\section{The Platonic dialogue as drama}

Until recently, the basis of drama was an inherited continuation of the Greek theatre ${ }^{16}$ and the Athenian theatre system, but the problem was that it could not gradually merge the progress and the developments that were constantly emerging. A key figure of the Athenian drama and its strong presence over the years, was Plato. The reader of Platonic dialogues is invited into the deconstruction and exploration of elements and positions that are validated through his critique of attitude, thereby leading more fully and thoroughly to the understanding of the philosophical questions. Plato manages to capture the teachings of Socrates and, at the same time, to some degree become the inventor of a theatre purged of doctrines and rules. The Platonic dialogues, structurally, seem to be accompanied by theatrical elements, but with one difference: they do not strictly apply to them, as they aim at pure intellect. The way in which dialogues are perceived has similar characteristics to those of theatre and, more specifically, to those of tragedy, because the spectator of tragedy proceeds to a process in which it is called upon to be evaluated. Correspondingly, platonic drama is of great value as it has the potential to offer self-evaluation and personal development through knowledge. Plato's drama, therefore, contains different elements and techniques, many of which appear in theatrical time and present a theatrical kind of conflicts. However, the differences and changes that are noted do not isolate it as a peculiar literature kens, but on the contrary reinforce its position, with more prominent being its originality in comparison with other philosophical or theatrical forms (Nussbaum, 2001: 126).

${ }_{13}$ It is true that the works by the above German authors have been recently translated and more and more being discussed in the English speaking environment (Heckmann, 2004; Leal, 2004; Nelson, 2004; Opening Mind Academy, 2011. www.openingmind.com or www.philosophicalmidwifery.com; Grondin, 2018).

14 According to Jan Slaby - Laura Candiotto states - Minna Specht by employing specific educational methods to create a proper setting for the inquiry, starting from bodily awareness, exemplifies in her methods certain contemporary debates in the philosophy of emotions and at the same time recalls the existential importance of the Socratic Dialogue for educational politics. See http://www.friesian.com/ where various fragments from Socrates Apology by Plato - together with Immanuel Kant, Arthur Schopenhauer et al. - inspires the principles of a critical rereading of philosophy as an open alternative to the theoretical dominance of either the Marxist or existentialist and poststructuralist era. Jakob Friedrich Fries (1773-1843) was a German post-Kantian philosopher.

15 In Plato's model of education Laura Candiotto also detects the importance and epistemic value of Eros, especially in the dialogic form of acquiring knowledge, referring to the dialogues Symposium and Alcibiades $I$. Besides the historical facts about the relationship of Socrates and his students (Alcibiades, being the most famous) and also apart from tracing the reality or not of their erotic friendship, the interesting part is how Plato transformed Eros to a tool and intrinsic motive for philosophical education (Candiotto, 2017b; cf. Brisson, 2016; Sassi, 2011).

${ }^{16}$ In the $5^{\text {th }}$ book of Vitruvius' De Architectura, end of 1st cent. BC., the Greek Theatre is described in geometrical detail as distinguished from the Roman type (Vitruvius, 1914, $151 \mathrm{ff}$ ), while two centuries later Pollux offers mainly details also (Pollux, 1824; cf. Baldry, 1971: Greek edition, 1992: 23). 
Plato, furthermore, manages to maintain an original attitude at a time when oral tradition prevails in Greek poetry, which in combination with fictional elements seems to affect an increasing number of people. ${ }^{17}$ In order to construct a dialogic drama, Plato must draw everyday pieces and use as many ways of propagation that would remain in the listener's mind. ${ }^{18}$ Plato

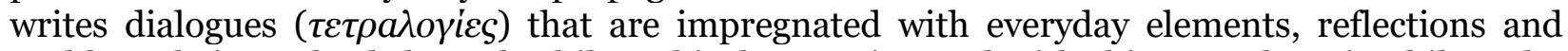
problems being solved through philosophical reasoning and with this way platonic philosophy manages to enter both the Athenian houses and their public debates. For Plato, his association with Socrates will prove to be a means of completing his spiritual path, which over the years will offer associations as well as conflicts with other sciences. Most characteristic is the conflict of philosophy with theatre, which has its origins almost with the creation of platonic drama and the placement of Socrates as a central personality in all Platonic dialogues. The basis for this conflict is constituted by modern performers as an additional critique of the Socratic intellect which aims to reveal the quality and immediacy of philosophical arguing that can be made possible mainly through theatre. ${ }^{19}$

Plato's ultimate goal in the Socratic dialogic critical discourse was to inaugurate a new form of drama that would rely on instruments and subjects of different content than the Athenians had been already used to. But this criticism must be perceived through an inner conflict between spoken and written discourse, between poetry and myth (Puchner, 2010). As mentioned previously, the platonic advent in the Athenian spiritual life aimed at educating the citizens and enriching the city's cultural history. Homer and the poets belong the past, as pieces of a tradition that begins to dwindle in the spread and development of language. Plato will reinforce this radical change in the facts of the Athenian theatrical reality, avoiding the old ways of creating and conveying his work while applying new methods such as: reading works by a performer in front of small audiences, setting the work in philosophical question and also, by avoiding spectacular movements and dance - chorus - acts (Puchner, 2010).

17 Plato criticizes myth, considering it as a communicative phenomenon. In this respect, myth faces two censures: it is neither a verifiable form of reasoning nor is it grounded on arguments. This fact, however, does not prevent Plato from recognizing usefulness in myth, making it often an integral part of his way of discourse (Brisson, 2006: 14). Moreover, this emotional ambivalence towards writing, which Plato echoes, reflects a comparable historical situation in ancient Greece. Indeed, the oral culture, the model of which was the Homeric epic, was not abruptly overwhelmed by a culture of writing, the appearance of which dates back to the $8^{\text {th }}$ century BC. Until the end of the $5^{\text {th }}$ century, even later, an important part of the ancient Greek civilization remained to be of an oral type (Ibid., 50).

18 This new theatrical form, which is mainly presented through Plato's dialogues and involves interesting issues of everyday life and scientific character, was adopted by many Socrates students; that is why Plato's connection to drama is a point of investigation by Aristotle and Diogenes Laertius. Diogenes Laertius particularly mentions Plato as a creator who was strongly associated with the Athenian theatre and sought everyday contact with it. It is also known that Plato had traveled along with the tragic poet Euripides and was influenced by the comedian and philosopher Epicharmos (Diogenes Laertius, 1925, III; Puchner, 2010, 4).

19 Plato's Socrates argues publicly of course about the various aspects of theatre as well as about the status of the actors (Republic, Ion), the characters of the Homeric epics (Republic), ridicules the principles of comedy (Republic), the gathering of large audiences (Laws) and finally throughs out in exile from his ideal state the tragic poets. When Socrates talks with Glafkon in the Republic, he refers to the conflict that previously existed between poetry and philosophy, and then he wonders if it would be beneficial to allow

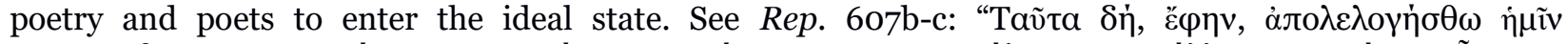

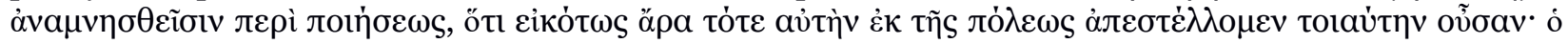

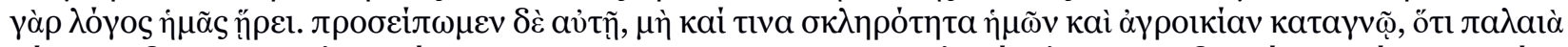

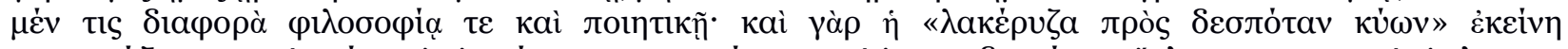

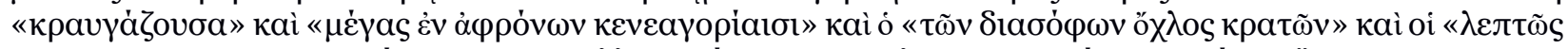

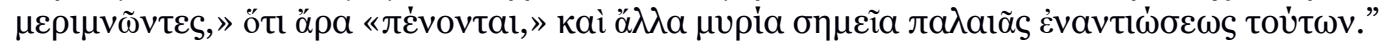


5. The therapeutic use of Platonic drama and Socrates as a dramatic figure

In Andrew Irvine's work we have a composition of texts and opinions to the extent that we could speak of the well-known method of theatrical adaptation of classical pieces, which was already used by such great modern theatre personalities like Bernard Shaw Jeam Annouille or Bertholdt Brecht. Irvine uses the Apology of Socrates through Plato and Aristophanes' Clouds. Many others wrote about Socrates but our author mainly takes into account Socrates' pleadings in court from two sources, Plato and Xenophon. Both present Socrates not accepting the unjust accusations imposed by the court of Heliaia; stating that he believed in the same gods with his fellow citizens and that he was never responsible of the corruption of youth. Words never heeded in the adulterated court. The "contribution" of his friend and pupil, Alcibiades, launched the condemnation of the great philosopher.

In Socrates on Trial, the first act belongs to the Clouds and the second to Apology. In the first, the comic atmosphere created by Aristophanes' mocking of the Sophists for their paid teachings and, on the other hand, the corruption that Socrates induces to young people, shape the theme of the play where the dominating moral question is about what is right and what is not. Socrates equates virtue with knowledge because he is concerned with the moral consideration of life, hence this belief led him to the definition of those ethical concepts that should govern life. Although Socrates did not teach sophistry, it is inherent in the satirical pen of Aristophanes and through the ideas about philosophy, as nebulous ideas, he replaces the city's gods with chaos, senseless chatter and dangerous beliefs.

The setup of the actors is done with a simple way, reinforcing the validity of Socrates' plea. Irvine in the first part of the Trial, places the spectator in a simple setting where the only thing that can be observed is a door ... the door leading to Socrates' school inside of which are the young minds and supposedly think in their "cloudy" atmosphere. Socrates himself is presented close to the clouds, in a high place, where it seems that he is conversing with the gods.

The author benefits from the spiritual power that Socrates inspires, thus, places him in a position that befits him, the highest of all. It is important to inculcate in our minds this point between anything earthly and the gods. Socrates becomes a communication channel. He leaves the pedestal where he is, and the secluded wise is transformed, that way, into the man from next door. ${ }^{20}$ Irvine with this simple way makes the best introduction on stage for Socrates.

In the second act of the play we find the "Apology". Socrates is placed among his critics (Melitus, Lycon, Anytus), the judges and the audience. Irvine essentially presents Socrates preparing the audience through his arguments for an unfair treatment towards him. The philosopher begins his speech to the audience and leaves room to be judged, even to be challenged as long as their arguments are governed by pure logic. If we perceive this particular scene as a theatrical act, we can then identify a detachment method of the speaker, because while he himself is creating the questions and providing the answers, under no circumstances does he succumb to feelings. His reasoning is valid, based on the correctness of his arguments, rendering a possible reliance on emotion unnecessary. To illustrate, when the judges asked him about the absence of his family during the hearing of the decision, Socrates cited the need for absence of an affective process on such issues, since the aim was to reach a decision by justice and not for the judges to be lured by the cries for the acquittal. The emotional stimuli would force the judge-spectator to be gone astray from his own logic and be "charmed'” only by the Socrates' words.

In the third part of the play, with the title Crito and Phaedo, Irvine thereby "completes" his own trilogy. The author by continuing with the Platonic dialogues gives us a

${ }^{20}$ In the words of Cicero, we find that first Socrates freed philosophy from the sky and settled it in the cities and in people's homes. So, from world theory philosophy became a lifelong art (Cicero, 1950, 5.4.10). 
A. Lazou \& G. Spyridis - Philosophical and Therapeutic Aspects of the Platonic “Drama”...

different perspective on Crito: ${ }^{21}$ Crito tries to change the opinion of Socrates and cites reasons that should lead him to want to escape. However, the great philosopher refutes the arguments, one by one, defending the validity of the acts and laws of the city. ${ }^{22}$ Irvine creates the right atmosphere ... with Socrates initially asleep and awaken by Crito. At this point, before the dialogue begins, we are being presented with the atmosphere of the epilogue. The scene starts with silence and concludes at the end again with silence. It opens with Socrates sleeping and closes with him "sleeping" eternally ... the viewer enters strongly with a simple method to the seriousness of the situation. During the course of the act, Socrates is presented even more centrally than before. His sayings are not borne by the stage placement of the participants (Crito, Xanthippe) but the play leaves room for experimentation. Crito assumes a humanitarian role, the role of the friend trying to help, to save Socrates. But Socrates has fully accepted his conviction and to a certain degree in the eyes of the spectators is no longer a human. He becomes one with the laws he defends and "secures" their correctness. Unique moments of relief are when the philosopher talks about his children and the education they should receive so as to lead an honest life.

Action on stage becomes more pronounced with the arrival of the executioner. There we distance ourselves from the theory of a successful "theatrical" act and we move practically to the transition ... to the "conium" scene, to the actual completion of the play. While the moments of emotion alternate with thoughtful moments, Socrates does not give any opportunity for the spectators to draw their gaze away from him. Perhaps to some extent, one wants to think that something will change in the end.

The executioner "erases" the course of events offering Socrates the conium, shortly afterwards, when the basic principle of physicality ends his task. Socrates as a stage figure works physically and follows a "fast" march towards death. He moves slightly on stage and ends up on the bed ... the scene develops through silent moves, something that transforms us from mere spectators into witnesses of an internal approval of death.

Slowness engulfs the once lively spectacle and the theatrical act is being completed. The actors' bodies are covered with immobility and just like that, free from words and stage aids, the viewer gets overwhelmed with feelings of sadness. Compliance with the law is an inviolable rule and acts as a reminder of the ideals that govern the city. Socrates does not bend under the pressure of his accusers, nor tries to hide behind the prowess of his word. He stands in front of the Athenian citizens and sacrifices his body to condemn the constitution of the city. The last day of Socrates has reached its end. The play in this theatrical form enables us to reflect, after the end, on the theory offered to us and to consider the seriousness of our acts: just before the final act the spectators were asked to get up and vote for or against the accused, to exchange even their thoughts with the judges and Socrates himself, interrogating or even protesting in case they/we disagree. So the modern man is not any more a spectator but an agent, a co-author of Socrates' fate!

This situation on stage permitted by the scenario of the original play but also by the thrilling Socratic figure itself, transforms a theatre play to a cathartic experience not only for the spectator as an individual psychological subject but also for the historical consciousness of each one of us: The catharsis of the city has come with the death of Socrates. But it is far less important because the loss of the great philosopher demonstrates the power of law and leaves us with a

${ }^{21}$ We may remember that Crito is part of the tetralogy (Euthyphron, Crito, Apology, Phaedo) dialogues mentioned in the trial and execution of Socrates. The characters of the dialogue are both Socrates and a close, wealthy friend of his, Crito.

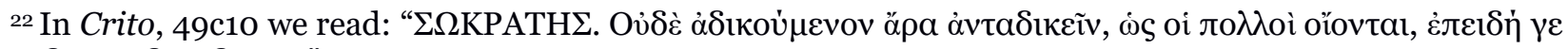

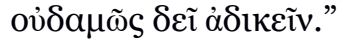


question: what is fair? It awakens us in regards to the politics and the human responsibility that creates a society.

The condemnation and death of Socrates can be regarded as a starting point for a new society that anyway would afterwards dominate in Athens in the $4^{\text {th }}$ century, and would offer to it its particular physiognomy (Mosse, 1962: 133). Symbolically, the act of revival of Socrates' story can be regarded as the restarting point for our contemporary society.

George Steiris points out that:

"Irvine seems to have adopted the analytical approach of the Platonic dialogues proposed by Gregory Vlastos in the $20^{\text {th }}$ century (Vlastos, 1983 ; 1991; Lazou \& Patios, 2017: 19). Apology and Crito are internally coherent and belong to the so-called Socratic period when Plato was under the strong influence Socratic teaching. As with the Aristophanic Clouds, so with the Platonic dialogues, Irvine chooses and reconstructs the core of argumentation, without attempting a tedious and impassioned passive reproduction of the ancient texts. The trial and death of Socrates left a heavy mark on human history. In addition to choosing to obey the laws and jurisdictions of the Athenian state, making him an example of political attitude, the fact that a few moments before his death, Socrates engaged in a dialogue about his life, confirms confidence in dialectics. The search for the good had not ended with Socrates even in his last moments. As Irvine rightly points out, Socrates accepted the verdict of his fellow citizens because, at the end of life, he remained a supporter of Athenian democracy. Socrates in the long period of war and political turmoil that preceded the trial, was never hidden or afraid to express publicly and support practically his opinions, even when they conflicted with established beliefs, the wills of different authorities and the changing moods of Demos. The last lesson delivered by Socrates, which unfortunately many subsequent philosophers have forgotten, was that in times of crisis the best way to offer services to yourself, your friends and your city is to obey to the laws and the public."

Konstantina Gongaki has also stressed the importance of Socrates' act of choosing death against moral humiliation, being the first Athenian philosopher in history to pay the price of his free opinions, being ahead and far beyond his time:

"Politics, however, was disrespectful to philosophy. A city, at a time of political upheaval and confusion, was not favorable to the philosopher, who often became annoying challenging the traditional values. Socrates had the fate of innocent people. In his face, history has since then reiterated the same pattern: enlightened consciences that break with political and social compatibility, which are not tacitly subordinated to the establishment, usually pay an expensive price. Socrates was immune to defending the truth, which without him would not have acquired its meaning, its very essence. His attempt was to persuade young people in palaestrae and fellow citizens in the agora to move to wisdom, virtue and justice (Gongaki, 2017). The price ( $\dot{\alpha} v \tau \imath i \mu \eta \mu \alpha)$ so simple, he claimed for himself and was not given to him, looks like the last wish of a man condemned to death or as an unfulfilled utopia. While he himself supported his ideas regardless of cost, although he deserved the

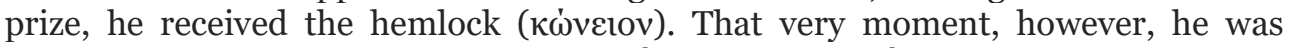

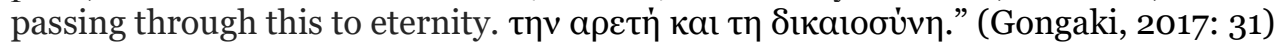

\section{Philosophy on stage as an imitation of life}

Facing the death of Socrates as something out of a scene from a play, it is possible to experience the emotional surge stemming from the atmosphere of the court. We become partakers or accomplices in the condemnation of the Greek philosopher. Through performance we listen and experience life events that stigmatize us, change us and in some cases help us evolve as to our own course in life. The theatrical stage is transformed into a land that is an integral part of our world 
and the art of theatre enactment is converted into the art of living. Theatre offers the opportunity to move into other lives and explore their perspectives. Theatre however has rules and through these very rules, the viewer rejoices or regrets, because the main purpose is to "feel" - in a physical way - the dramatic situation.

The encounter of philosophy and theatre in Plato's works is evidenced by elements pointing to action. These are summarized in (a) the empirical observation, (b) the progressive evolutionary critique of an argument given either by Socrates or by a third party; (c) the description of an intellectual example by the interlocutor and finally (d), the comprehension of the philosophical path to be followed in the conclusion (Monoson, 2000: 207-208). These elements appear individually throughout the platonic corpus but they all appear together only in one project, in the Republic. The above elements responsible for the propagation of the Socratic teaching are points where contemporary performers are divided in whether to apply them or not. Such a dimension of the problem lies in Plato's ability to write dialogues for their theatrical performance, so to steer people towards philosophy rather than poetry. Plato seems to have been aware of the difficulty of such a venture, so his dialogues tackled with everyday issues and problems that were of concern to the Athenian citizen (Ibid.). At the same time, the platonic dialogue was taking care of the criticality and the cultivation of the imagination of the citizens by creating strong emotions. Such an emotional state was sought out because it created the basis for liberation and empowerment of intellect (Ibid., 211).

A key point between philosophy and theatre is the reader-viewer position. In recent studies we find that the reader of the platonic dialogues is invited to the deconstruction and adoption of elements and positions, which are validated through his critical attitude. In more detail, it is legitimate for the reader to critically analyze the essence of the dialogues to better understand their content. But the platonic drama is of great value because it has different constituents from those that existed at that time in theatrical texts.

Plato's allegorical myths and metaphors (the winged chariot of the soul, the beast of the soul, the cave etc.) have the appropriate thematic structure to be perceived through a new interpretative model, which combines the dramatic and the psychological criterion with philosophy. These different approaches combined are capable of imparting mental changes and extensions that the Platonic moving soul performs "willingly". The human soul imprisoned within the body is renewed seeking its contact with the material world by touchable examples that have to do with all aspects and functions of man such as arts, dance, music, painting etc. A dance flick, a theatrical interpretation, the rehabilitation of the body-soul balance is nothing but signs of the transforming oppressed freedom of the soul, which points in the end to the unifying power of life.

The conclusions for the relationship between art and therapy become reasonable by reference to their philosophical source: at first hand there is a connection between art and philosophy as far as their therapeutic uses. This is a reality proved by the most characteristic examples of ancient Greek drama as well as the platonic dialogues. Both drama and philosophizing are human actions recognized by such major philosophers, like Socrates or Wittgenstein, as implying a dynamic interaction with their agent. In the past these two examples or paradigms of human action have not always been conducted as we can see in the case of the nietzschean critique against Socratic rationalism in contrast with the tragic wisdom of the Greek playwrights.

\section{In Professor Kaldis' words:}

"So in our production we have a rather fortunate combination of the recent advances in the philosophy of performance and staging on the one hand, and the critical task of theatre, on the other. In fact this time the play has a double edge: while carrying on its critical engagement with political and ethical issues societies have been usually concerned about, it also targets its criticism on philosophy as such and its place within this wider political goals. The self-referential criticism of philosophy is of 
course as old as itself. Its dovetailing with a play has abated for centuries and it is therefore quite auspicious that is happening here in Athens today. It is also very timely at times of crisis, needless to say." (Lazou \& Patios, 2017: 7-10)

\section{Acknowledgements}

This research did not receive any specific grant from funding agencies in the public commercial, or not-for-profit sectors.

The authors declare no competing interests.

\section{References}

Baldry, H. C. (1971). The Greek tragic theatre. London: Chatto and Windus. Greek Edition: (1992). To

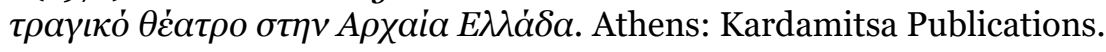

Brenifier, O. (2017). The art of philosophical practice. Paris. http://www.pratiques-philosophiques.fr/wpcontent/uploads/2015/08/The-art-of-philosophical-practice-mise-en-page-1.pdf.

Brickhouse, C., \& Smith, N. (1994/2004). Plato’s Socrates. Oxford: Oxford University Press.

Brisson, L. (2006). Plato, the words and myths (Greek edition). Metaichmio Publications.

... (2016). Éros éducateur: entre paiderastía et philósophia. In: M. Tulli, M. Erler (eds.), Plato in Symposium. Selected Papers from the Tenth Symposium Platonicum (pp. 24-35). Sankt Augustin.

Broad, W. J. (2006). The oracle. New York: Penguin Books, Ltd (Penguin Group-USA).

Brown, Th. K. (ed.), (1965). Socratic method and critical philosophy. Selected essays by Leonard Nelson. New York: Dover Publications.

Candiotto, L. (2017). Socratic dialogue faces the history dialogical inquiry as philosophical and politically engaged way of life. (Preprint published version) Culture and Dialogue 5, 157-172. http://booksandjournals.brillonline.com/content/journals/10.1163/24683949-12340031.

Cicero [Marcus Tullius] (1950). Tusculan Disputations (transl. J. E. King). Cambridge: Loeb Classical Library, Harvard University Press.

Corey, G. (2001). Theory and practice of counseling and psychotherapy. CA: Brooks/Cole.

Cornford, F. M. (1996). Before and after Socrates. New York: Cambridge University Press.

Diogenes Laertius (1925). Lives of eminent philosophers, 2 vols. Book III. Transl. R. D. Hicks. London: Loeb Classical Library, Heinmann.

Foucault, M. (2005). The hermeneutics of the subject. New York: Palgrave Macmillan.

Glover, J. (2014). Alien landscapes? Interpreting disordered minds. Harvard University Press.

Grimes, P., \& Uliana, R. (1998). Philosophical midwifery: A new paradigm for understanding human problems with its validation. California: Hyparxis Press.

Gross, R. (2002). Socrates'way: Seven keys to using your mind to the utmost. Tarcher Perigee Publications.

Heckmann, G. (1981). Das sokratische Gespräch, Erfharungen in philosophischen Hochschulse minaren [Socratic dialogue, experiences in high school classes]. Hannover: Schroedel.

Irvine, An. D. (2008). Socrates on trial. Toronto: University of Toronto Press.

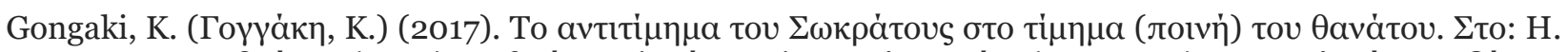

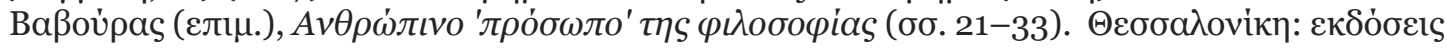


A. Lazou \& G. Spyridis - Philosophical and Therapeutic Aspects of the Platonic “Drama”...

Pó $\mu$ (Socrates' price difference to death penalty. In: El. Vavouras (ed.), The Human 'Face' of Philosophy (pp. 21-33). Thessaloniki: Romi Publications).

Grondin, A. J. (2018). Effectiveness of the Socratic method: A comparative analysis of the historical and modern invocations of an educational method. Senior Theses. University of South Carolina, Scholar Commons.

Heckmann, G. (2004). Six pedagogical measures and Socratic facilitation. In: Enquiring minds, Socratic dialogue in education. R. Saran \& B. Neisser (Eds.). VA: Trendham Books, Ltd.

Kojčić, Z. (2019). Performance oriented philosophical counseling and its application in IT companies. HASER. Revista Internacional de Filosofía Aplicada, (C) Universidad de Sevilla Broader, no 10, 93-120.

Lahav, R. (1996). What is philosophical in philosophical counseling? Journal of Applied Philosophy, 13(3), 259-278.

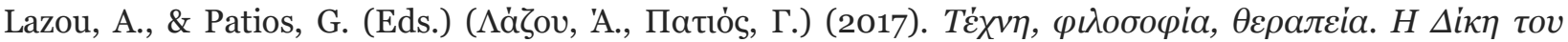

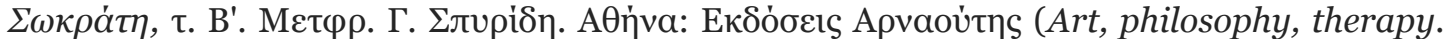
Socrates on trial, v. B'. Transl. by G. Spyridis. Athens: Arnaoutis books). ISBN: 978-960-964$53-7$.

Lageman, A. G. (1989). Socrates and psychotherapy. Journal of Religion and Health, 28(3), 219-223.

Leal, F. (2004). Introduction to L. Nelson's The Socratic Method. In: Enquiring minds, Socratic dialogue in education. R. Saran \& B. Neisser (Eds.). VA: Trendham Books, Ltd.

LeBon, T. (2001). Wise therapy: Philosophy for Counsellors. Sage.

Marinoff, L. (1999). Plato not Prozac! Applying philosophy to everyday problems by Lou Marinoff. Harper Collins Publishers: Reviewed by T. B. Munteanu. http://www.friesian.com/munteanu.html.

Miller, J. C. (2004). The transcendent function: Jung's model of psychological growth through dialogue with the unconscious. New York: State University of New York Press.

Monoson, S. (2000). Plato's democratic entanglements Athenian politics and the practice of philosophy. Princeton University Press.

Mosse, C. (1962). La fin de la démocratie athénienne: aspects sociaux et politiques du déclin de la cité grecque au IV siècle avant $J .-C$. Presses universitaires de France.

Nelson, L. (1970). Gesammelte Schriften. Vol. 1: Die Schule der kritischen Philosophie und ihre Methode (Collected Writings. Vol. 1: The School of Critical Philosophy and its Method). Hamburg: Felix Meiner Verlag.

Nussbaum, M. (2001). Fragility of goodness - Luck and ethics in Greek tragedy and philosophy. Cambridge University Press.

... (2017). On the epistemic value of eros. The relationship between Socrates and Alcibiades. PEITHO/EXAMINA ANTIQUA, 8(1), 225-236.

Opening Mind Academy (2011). www.openingmind.com or www.philosophicalmidwifery.com.

Overholser, J. C. (2010). Psychotherapy according to the Socratic Method: integrating ancient philosophy with contemporary cognitive therapy. Journal of Cognitive Psychotherapy, 1-14 (Retrieved from: www.findarticles.com).

Padesky, C. A. (1993). Socratic questioning: Changing minds or guiding discovery? Keynote address delivered at the European Congress of Behavioral and Cognitive Therapies, London, 24 September, 1-6. Retrieved from www.padesky.com/clinicalcorner/pdf/socquest.pdf.

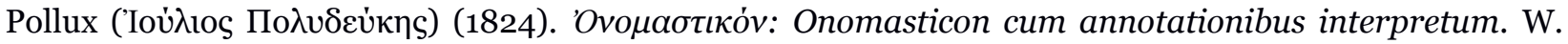
Dindorf (ed.), 3 vols. Lipsiae in libraria kuehniana.

Puchner, M. (2010). The drama of ideas: Platonic provocations in theatre and philosophy. Oxford University Press. 
Raabe, P. B. (2001). Philosophical counseling: Theory and practice. Wesport, CT: Praeger.

Sassi, M. M. (2011). Eros as psychic energy. Plato and fluxes of the soul. In: M. Migliori, L. Napolitano Valditara, A. Fermani (Eds.), Inner Life and Soul. Psychê in Plato (pp. 251-265). Sankt Augustin.

Slaby, J. (2008). Affective intentionality and the feeling body. Phenomenology and the Cognitive Sciences, 7(4), 429-444.

... (1929). Die sokratische Methode. Vortrag, gehalten am 11. Dezember 1922 in der Pädagogischen Gesellschaft in Göttingen (The Socratic method. Lecture held on the $11^{\text {th }}$ of December 1922 in the Pedagogical Society in Gottingen). In: O. Meyerhof, Fr. Oppenheimer, M. Specht (Eds.), Abhandlungen der Friesschen Schule. Neue Folge, Band, H. 1 (Friesian School's memoirs. New Series, Volume H. 1) (pp. 21-78). Gottingen: Offentliches Leben.

... (1991). Socrates: Ironist and moral philosopher. Cambridge: Cambridge University Press.

... (2004). The Socratic Method. Intro. F. Leal. In: Enquiring minds, Socratic dialogue in education. R. Saran \& B. Neisser (Eds.). VA: Trendham Books, Ltd.

Specht, M. (1944). Education for confidence. A school in exile. London: New Education fellowship.

Vitruvius (1914). Ten books on architecture (transl. by M.H. Morgan), Book V. Harvard University Press.

Vlastos, Gr. (1983). The historical Socrates and Athenian democracy. Political Theory, 11, 495-516.

Walsh, R. (2005). Philosophical counseling practice. Janus Head, 8(2), 497-508. 
A. Lazou \& G. Spyridis - Philosophical and Therapeutic Aspects of the Platonic “Drama”...

C O A $\mathbf{s}$ 